\title{
The Winning Of The Partai Aceh In A Psychological Political Approach
}

\author{
Mukhrijal $^{1}$, Saddam Rassanjani ${ }^{2}$, Herizal ${ }^{3}$, Afrijal $^{4}$ \\ 1,2,3,4Universitas Syiah Kuala, Jl. Teuku Nyak Arief No.441, Kopelma Darussalam, Syiah Kuala, Banda Aceh City, Aceh 23111 . \\ Indonesia \\ Corresponding Author: muhkrijal@unsyiah.ac.id \\ doi https://doi.org/10.18196/jgpp.v8i2.11586
}

Article Info

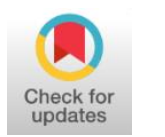

Article History;

Received:

2021-04-06

Revised:

2021-05-05

Accepted:

2021-06-14

\begin{abstract}
Partai Aceh is one of the local political parties in Aceh that won the first political contestation in 2009, even though it was only born two years before in 2007. Since then, they have continued to dominate elections at the local level. Partai Aceh was established because of the peace agreement between GAM-RI as a post-conflict political agreement. The purpose of this study was to determine the victory of the Partai Aceh in the local realm. The method used was descriptive qualitative through interview techniques. The results indicated that the Partai Aceh's success in Acehnese local politics could not be separated from political psychology, such as the Partai Aceh identification approach through political socialization, political candidates, and the Partai Aceh political campaign. The Partai Aceh approached the community involving the former Free Aceh Movement in conducting campaigns. The Partai Aceh's foresight in carrying the figure of a former GAM combatant impacted the Partai Aceh's victory.
\end{abstract}

Keyword: Partai Aceh; Political Psychology; Aceh.

\section{INTRODUCTION}

The regional head election is a long series of processes for determining the regional head who will lead the region for five years for one period (Aspinall and Mas'udi, 2017). The success of regional elections in Indonesia is regulated in Law Number 15 of 2011 concerning Elections, one of the rules in the post-conflict local election process. Law Number 15 the Year 2011 Article 1 on the General Election Commission (KPU) states that the KPU is an independent national election management body tasked with holding elections (Putra, 2013; Nuryanti, 2015). KPU is the election organizer at the central and provincial/regulatory/city levels; it is called the Provincial/Regency/City KPU, except in Aceh Province, which has a unique feature regarding election organizers by the Independent Election Commission (KIP).

In-Law Number 11 of 2006 concerning Aceh Governance in Article 56 paragraph 1 it reads, the Aceh Independent Election Commission (KIP) holds a general election for the President/Vice President, members of the People's Representative Council, Regional Representative Council, or DPRA, and Governor/Deputy Governor. Article 56, paragraph 2 of the law states that the Regency/City level holding the election is the Regency/City KIP. In the 2009 legislative elections, this local party was overwhelmingly welcomed by the public. The Partai Aceh (PA) managed to come out as the winner by quite a landslide percentage. The DPRA seats won 46.91 per cent of the votes, defeating national parties, such as the Partai Golkar, the Partai Demokrat, the Partai Amanat Nasional (PAN) and the Partai Persatuan Pembangunan (PPP) (KIP Aceh, 2009). The Partai Aceh's victory in the 2009 legislative elections can be seen in Figure 1. 


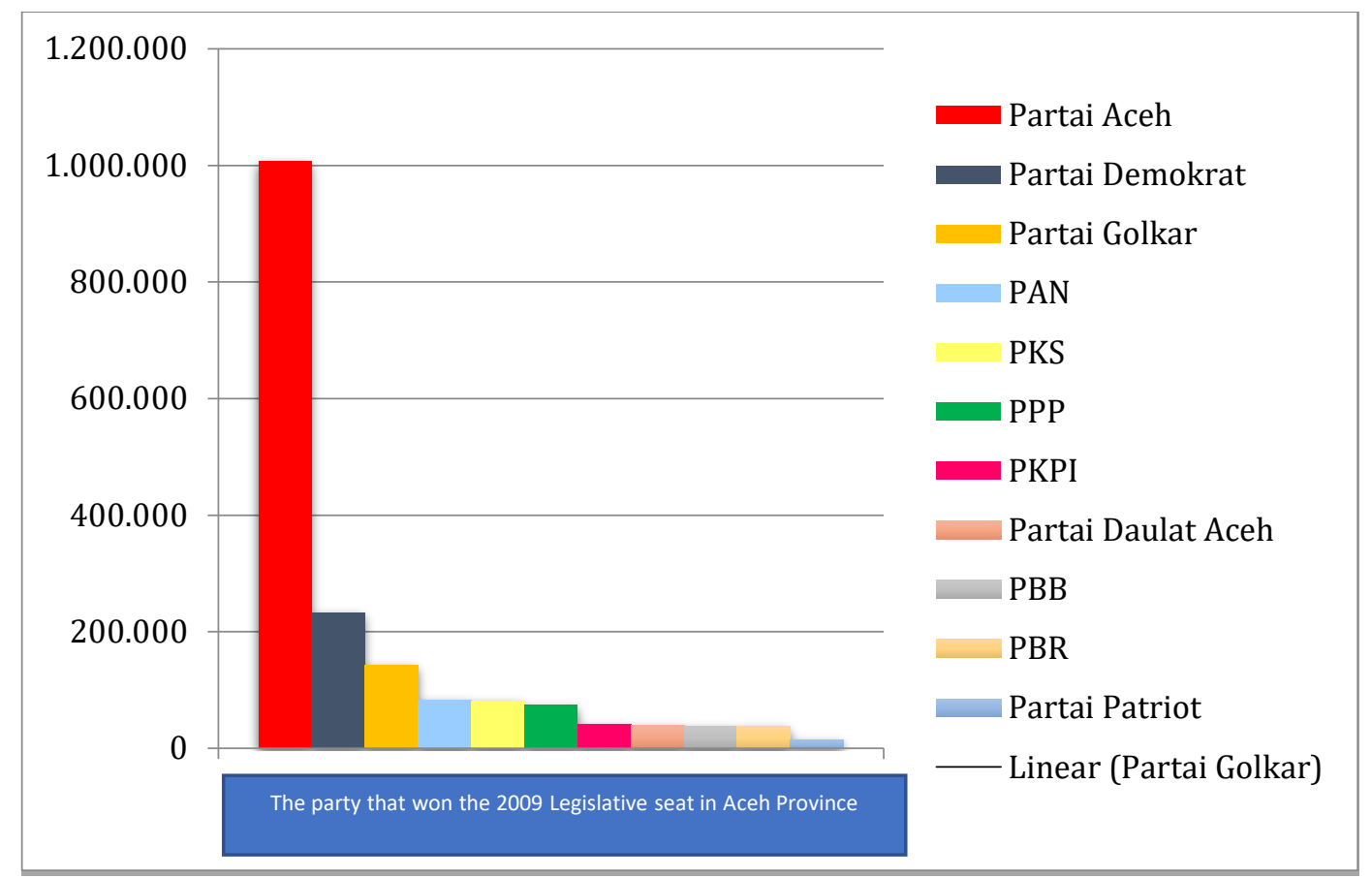

Figure 1. Legislative Seat Acquisition in 2009

Source: Aceh KIP data, 2009

The victory of the Partai Aceh at the Aceh Province level was extraordinary, winning around $1,007,173$ votes $(46.91 \%)$ by obtaining 33 seats, followed by the Partai Demokrat (PD) with 232,728 votes $(10.84 \%)$ with ten seats. The Partai Golongan Karya (Golkar) had 142,411 votes (6.63\%) with eight seats; The Partai Amanat Nasional (PAN) with 83,060 votes (3.87\%) and five seats; Partai Keadilan Sejahtera (PKS) with 81,529 votes (3.80\%) and obtained four seats; The Partai Persatuan Pembangunan (PPP) with 73,964 votes (3.45\%) and obtained four seats. One seat each occupied by the Partai Keadilan dan Persatuan Indonesia (PKPI) with 41,278 votes (1.92\%), the Partai Daulat Atjeh (PDA) 39,706 (1.85\%), and the Partai Bulan Bintang (PBB) 37,336 (1.74\%), Partai Bintang Reformasi (PBR) 37,025 (1, 72\%) and the Partai Patriot 15,054 (0.70\%). These results came from the recapitulation of 23 districts/cities out of 2,146,141 valid votes (KIP Aceh, 2009).

Barter (2011) argued that the Partai Aceh (PA) victory in the 2009 elections was an honest response to the hopes for peace and the aspirations of the Acehnese people. The victory of the Partai Aceh cannot be separated from the strategies implemented by the Partai Aceh, such as political ideas, political issues, political campaigns, election campaigns, party ideology, the influence of charismatic ulama, and also the work programs carried out by the Partai Aceh to the community both at the provincial and district/city levels. Political strategy is a strategic step played by political parties to influence voters to support them in elections (Borah, 2016).

In the 2012 election for the Governor and Deputy Governor of Aceh, the Partai Aceh still won the trust of the Acehnese people. The Partai Aceh victory cannot be separated from the participation of the community in giving their voting rights in the election. Voter behavior determined the achievement of the Partai Aceh at that time. The triumph of the Partai Aceh was the success of a political strategy carried out through a political, psychological approach in party identification, political candidates, and political campaigns to influence the public in choosing the Partai Aceh. This condition is proven by winning candidate pairs Zaini Abdullah and Muzakir Manaf, representing Partai Aceh in 2012, as seen in Figure 2. 


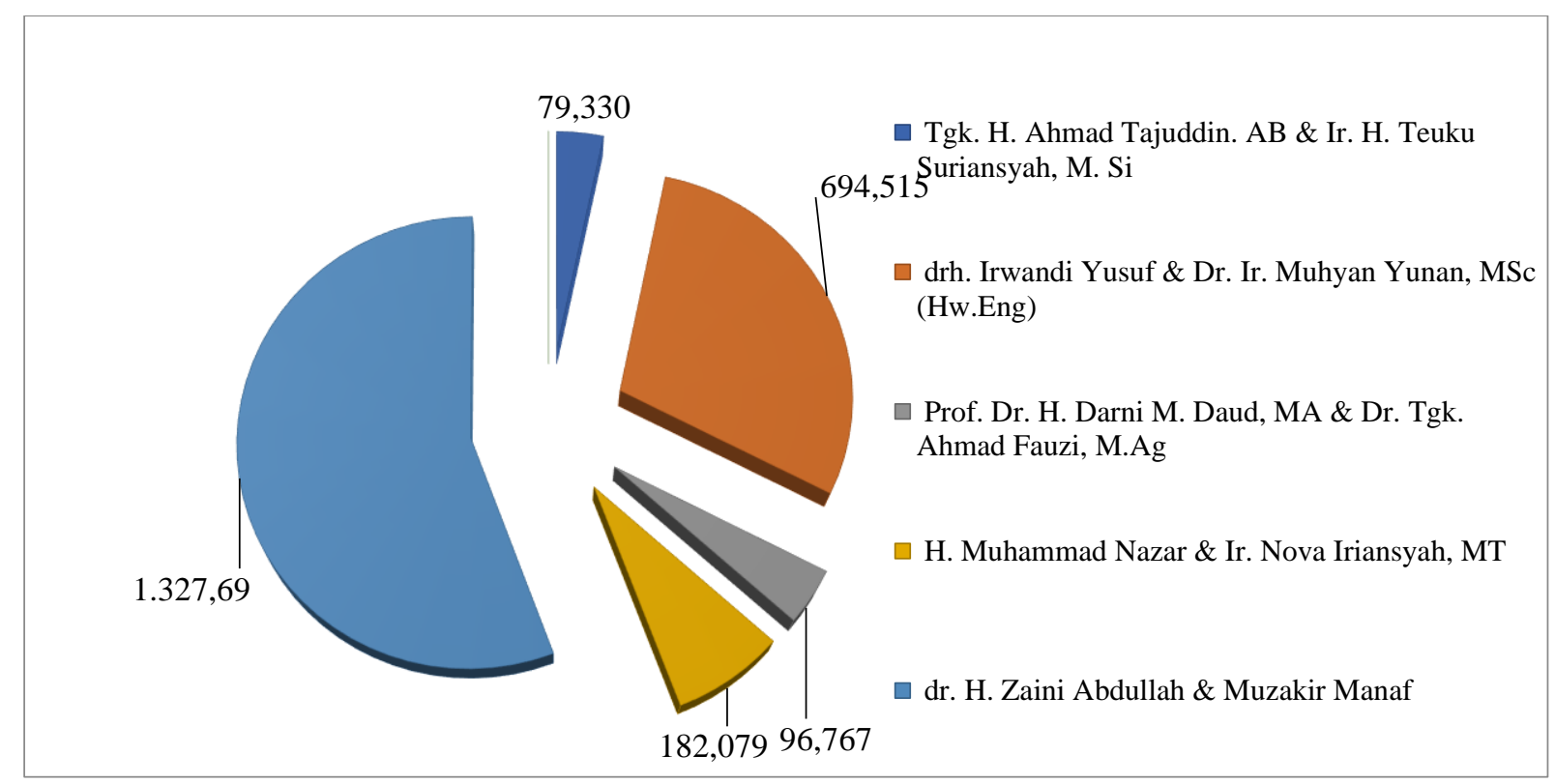

Figure 2. 2012 General Election of the Governor and Deputy Governor of Aceh

Source: Aceh KIP data, 2012

Based on Figure 2, the candidate pair number 5 dr. Zaini Abdullah and Muzakir Manaf, promoted by the Partai Aceh (PA), beat other gubernatorial candidates. For more details regarding the results of the vote acquisition in 23 districts/cities in Aceh, see Table 1.

Table 1.The victory of the Partai Aceh in the 2012 Election for the Governor-Deputy Governor of Aceh in 14 districts/cities out of 23 districts/cities in Aceh

\begin{tabular}{clccll} 
No. & $\begin{array}{c}\text { Regency/ } \\
\text { city }\end{array}$ & Number of Votes & No. & $\begin{array}{c}\text { Regency/ } \\
\text { city }\end{array}$ & Number of Votes \\
\hline $\mathbf{1}$ & Aceh Besar & $72,276(40.11 \%)$ & 8 & Aceh Jaya & $27,567(64.63 \%)$ \\
\hline $\mathbf{2}$ & Pidie & $166,237(74.66 \%)$ & 9 & Aceh Barat & $55,642(56.75 \%)$ \\
\hline $\mathbf{3}$ & Pidie Jaya & $53,379(68.72 \%)$ & 10 & Nagan Raya & $49,040(57.72 \%)$ \\
\hline $\mathbf{4}$ & Bireuen & $123,729(57.62 \%)$ & 11 & Aceh Barat Daya & $54,049(72.21 \%)$ \\
\hline $\mathbf{5}$ & Aceh Utara & $212,927(76.32 \%)$ & 12 & Aceh Selatan & $57,271(53.30 \%)$ \\
\hline $\mathbf{6}$ & Lhoksemawe & $50,355(61.97 \%)$ & 13 & Simeulue & $20,949(49.26 \%)$ \\
\hline $\mathbf{7}$ & Aceh Timur & $137,487(73.43 \%)$ & 14 & Gayo Lues & $32,497(68.19 \%)$ \\
\hline & \multicolumn{2}{c}{ Source: Aceh KIP data, 2012 } &
\end{tabular}

Partai Aceh's success in the 2012 Aceh Pemilukada was challenging. It took a long process in formulating a political strategy to gain victory considering that Partai Aceh's tough competitors were one of the former Free Aceh Movement (GAM), Irwandi Yusuf, and Muhammad Nazar strong influence in Aceh. Both of which are incumbents. During the 2012 Pemilukada for the Governor and Deputy Governor of Aceh, the former Free Aceh Movement (GAM) had internal conflicts and was split into three candidates for governor. First, Irwandi Yusuf, whom several GAM opponents support. Second, dr. Zaini Abdullah and Muzakir Manaf are supported by former GAM and also the Partai Aceh. At the same time, the third is Muhammad Nazar, who was the deputy governor at that time. The internal division of GAM is not an easy matter for the Partai Aceh in influencing the community to determine its choice to elect the Partai Aceh. A precise political strategy is needed to understand the character of voters, considering that the Acehnese are a society whose majority are traditional voters. Psychological approaches are required to influence voters, such as emotional relationships, kinship, and community sympathies.

As known, Aceh is the only province in Indonesia that has special rights in regional political arrangements. Aceh is famous for its political history, solid local ethnicity, and regional 
primordialism as one of the main reasons people respond to specific candidate pairs. If a candidate has the same primordial bonding background as the primordial bonding community, it is the community's choice. This emotional bond is a crucial consideration for society to make choices. The influence of these figures had an impact on the results of the post-conflict local elections in Aceh. Based on the facts above, it is interesting to analyse the psychological approach used by the Partai Aceh to achieve victory in local political contestation.

The study of political psychology is a field that has developed rapidly in recent years (Grimmelikhuijsen et al., 2017). Psychology has explained political behaviour for many years, but its application to politics has exploded since the early 1970s. This field began in the 1920s with the study of personality and politics, particularly with the psychoanalytic study of political leaders. As time and psychological understanding of personality developed, political psychologists began to look at personal characteristics, such as motivation and traits, in their political leaders' analyses (Houghton, 2014). The next wave in the development of political psychology was marked by a growing interest in the systematic study of public opinion and voting behaviour in the United States. Starting in 1952, Researchers at the University of Michigan began collecting survey data about public opinion and voting preferences. Since the publication of The American Voter by Campbell et al. in the 1960s, the tradition of using political psychology to study public attitudes towards politics began (Houghton, 2014; Cottam et al., 2016). The study subsequently developed into a complex theory and is perhaps the most influential in studying American political behaviour (Huddy, 2013).

Political psychology has developed rapidly over the past two decades. A sign of evidence of this trend is the increasing number of new books published on the theme of political psychology, including edited books (Borgida et al., 2009; Sinnott and Rabin, 2020), a textbook (Cottam et al., 2016), and handbook (Huddy et al., 2013). Besides reflecting the tendency to integrate biological and social processes, political behavior is increasingly explained by neurological and genetic models (Marcus, 2012; Staerklé, 2015). The relationship between biopsychology and political orientation becomes more apparent with each new study. Liberals and conservatives think differently (Eidelman et al., 2012; Talhelm et al., 2015), process emotions differently (Ahn et al., 2014), see the world differently (Hetherington \& Weiler, 2018).

Campbell et al. (1960) stated that choice-making and choice decisions are psychological theories. He argues that voters hold several attitudes about issues and candidates. The theory used is a psychological theory to identify political parties, political candidates, and campaigns to analyse this research.

\section{Party Identification}

Campbell et al. (1960) mentioned several attitudes in voters, including the following: (i) How does someone feel about Democrats; (ii) How do you feel about the Republic; (iii) How each party manages the government; (iv) How well does the party manage interest groups; and (v) How well does the party manage foreign relations. These attitudes constitute the identity of the party that will guide the determination of one's choice. Campbell (1960) says this attitude can influence voters to determine which candidate will be elected by providing favourable policies that cause voters to vote for him. A positive attitude towards elections built in an environment will significantly affect someone who comes from that environment. According to the party values they believe in, parents who support specific political parties will also tend to foster a party attitude in their family members.

The process of building a perception of someone's political attitude due to the operation of political socialization through political outreach in the family, workplace, and community environment helps the process of forming party identity. Campbell et al. also mentioned that someone has a logical attitude when making choices (Ishiyama and Breuning, 2013). They said the issue was inconsequential if the voters made their choice. Individuals have positive and negative attitudes towards candidates or political parties, so this will guide their choices.

Campbell et al. (1960) mentioned that voters develop lasting psychological connections with political parties. Psychological links to political parties will colour the formation of a person's attitude so that later voters will be embedded in determining their choice. Therefore, psychological 
connections with political parties will influence the choice of voters (Ishiyama and Breuning, 2013). According to Campbell et al. (1960), the observed connection between voters and parties is the voter's agreement with the party. Nevertheless, identification can change when one examines the relationship. If this happens, party identification will not color attitudes, and explanations about choice determination may not be accurate (Ishiyama and Breuning, 2013).

\section{Political Candidates (Personality)}

Voters will judge and weigh which candidate will stand for and represent their vote. A candidate who is the identity of a political party offered to voters must understand the characteristics of the voters. Newman and Sheth (1985) state that the development of voter behavior models is based on several dominant marketing-related issues such as personal events and epistemic matters.

a) Personal Events

b) Newman and Sheth (1985) stated that personal events refer to individual lives and events that political candidates have personally experienced during their career before becoming a political candidate. This variable is crucial to find out the personal circumstances of a political candidate. Events about these political candidates will generally affect the mindset and decision-making if a candidate wins the general election. From individual events, these indicators include figures from these candidates such as a kai/ulama, the daughter of a former president, a reformist figure, an activist, a professor, a businessman, and even a public figure (Sugiono, 2013).

c) Epistemic Issues

Epistemic Issues are specific electoral issues and will spark voters (voters)about new things. Newman and Sheth (1985) stated that epistemic issues would arise amid public distrust of political institutions that are part of the current system, such as a figure capable of eradicating corruption, overcoming crises, and providing security guarantees for the public. In 1976 and 1992, the presidential elections of the United States showed empirical evidence that specific issues can influence voter behavior (Sugiono, 2013). Some voters represent a candidate outside the mainstream and will be seen as candidates who will do something different and unique from an existing political tradition-issues of the candidate's ability to provide health insurance.

\section{Campaign}

In addition to identifying political parties and candidates, Campbell et al. (1960) also cited that other factors are correlated with voters (voting), namely an interest in the campaign; those interested in the campaign are also more likely to vote. However, they also argued that interest in campaigns would not necessarily lead people to vote. However, someone is interested in the election if the voters already have the decision to vote (Ishiyama and Breuning, 2013).

The campaign became an arena for political maneuverer to attract as many voters as possible in an election to seize power. There are various ways to gain control, including making promises to the public or voters that sometimes do not make sense. Political parties sometimes use excuses such as building a just and prosperous area, even intimidation to come to power (Firmanzah, 2012). After the election was over and succeeded in gaining control, many political parties forgot their promises during the campaign or election. Incidents like this often occur in developing countries like Indonesia so that the level of trust (electability) of the people towards political parties decreases.

The political campaign is a period given by the election committee to all eligible participants, both political parties and individuals, to present work programs, influence public opinion, and mobilize the public to elect political party candidates at the time of voting (Firmanzah, 2012). Here we can see that the political campaign is a long-term process that concerns the consistency and continuity of political parties; therefore, political campaigns must be carried out intensively (Firmanzah, 2012).

This campaign is seen as mass gathering, political speeches, and party attributes such as banners, posters and banners, and party advertisements. In this case, the time has been determined by the committee. Official rules have also been set during the campaign. Moreover, if it does not follow the rules developed, it is considered violating and will get a penalty. Such a campaign will end with a vote to determine who will receive the most support to be declared the 
winner. In this case, there are two types of campaigns: political campaigns that are permanent in nature or long-term campaigns. Furthermore, the second is the campaign leading up to the election, a short-term competition arena.

\section{Political Campaign}

A political campaign is closely related to the formation of a political image. Political campaigns have an essential role in building a political vision which will later influence voter behavior in evaluating the quality of election contestants (Firmanzah, 2012). Through the concept of a permanent campaign, political marketing becomes a concept of managing political strategies and activities related to a party's political policies and work programs. Phenomena like this have shown that political marketing has become a political strategy in marketing (Firmanzah, 2012). In this case, political parties must demonstrate their concern for the community and respond to social symptoms to get sympathy from voters. In this case, political parties carry out a long-term strategy.

The long-term strategy is a strategy carried out continuously by political parties to build a political image and gain influence compiled through political party programs with a mechanism established by the party internally by conducting political campaigns. Political campaigns are generally carried out in public meetings containing various speeches, talks, the delivery of slogans, whether in printed or recorded form containing invitations, persuasions, pictures, or sound and symbols campaign (Sayuti, 2014). Thus, political campaigning is an essential part of political marketing because it gains influence in society. It cannot be done instantly and takes a long process using a systematically composed political party to gain the public's trust.

\section{Election campaign}

The election campaign is a political activity that aims to lead voters to the voting sites. Shortterm movements are characterized by the high costs that each political party or contestant must incur. This campaign focuses more on external activities. In an election campaign, the most crucial thing is refreshing and strengthening people's memories about what political parties have done. The short-term election campaign has limitations; because voter preferences for specific candidates have been formed long before the election campaign begins (Firmanzah, 2012). Voters' importance cannot be created only by short-term movements. The short-term campaign strategy leading up to the election must be supported by a long-term campaign that is continuous. The campaign seeks to shape collective behaviour so that people are more easily motivated to win the election.

The short-term strategy is a strategy used before the general election is held, usually by following the rules set by the general election commission. The focus of this short-term strategy is applied more to mass mobilization, namely by going down directly to seek support. It is essential to do considering the increasingly fierce competition in the election to compete with each other in chasing the masses. Also, the mindset of constituents tends to change at the stage leading up to the election. With a short-term strategy, apart from hunting for the masses, it is also possible to protect voters from moving to other parties. The most important part of the short-term strategy is the election campaign. Schroder (2004) instructed political parties to have several conditions that must be considered in an election campaign: (i) the party is oriented towards a new and complementary program; (ii) when new programs are introduced, party profiles must also change; and (iii) existing programs must be tailored to individuals to demonstrate alignment between programs and individuals. New programs or themes cannot emerge suddenly; therefore, the incumbent or mandate holder must have been prepared through a personal development program.

\section{RESEARCH METHOD}

This study used a qualitative descriptive research method to examine the victory of the Partai Aceh in a political, psychological approach from the aspects of party identification, political candidates, and campaigns. Qualitative methods, where research produces descriptive data in written or spoken words from people who can be observed. The data can be from interviews, field notes, photos, videotapes, secondary data in the form of documentation, notes or memos, official documents, questionnaire surveys, and others (Moleong, 2007). The types of data used in this 
study were primary data and secondary data. Preliminary data came directly from the field or object under investigation. The thing understudy is people who understand and know the problem. Secondary information is supporting data obtained from documents electrically and related to the problem.

In addition, this study collected secondary data sourced from documentation in agencies such as the Partai Aceh Office, Government, Private, and Community Organizations in Aceh Province, such as the KIP Office and others. Direct interviews conducted data collection techniques to obtain data and information from natural sources whose data were related to the meaning behind the Partai Aceh's victory. The sample was taken by purposive random sampling of those directly involved in the Partai Aceh victory or understanding the issues. The collected data were processed and then analyzed to make conclusions as a result of the research. The data analysis method was descriptive. The procedure in which the data obtained was collected and then interpreted to provide information about the real problem based on the data gathered from the study.

\section{RESULT AND DICUSSION \\ Political Psychological Approach}

The victory of political parties in a democratic party is motivated by various influencing factors. One of which is political psychology. Campbell et al. (1960) stated that voters develop lasting psychological relationships with political parties. Psychological connections with political parties will color the formation of a person's attitude so that later voters will be embedded in determining their choice. Therefore, psychological relationships with political parties will affect voter choices (Ishiyama and Breuning, 2013). The political-psychological approach consists of three influencing elements: the dimensions of party identification, political candidates, and the campaign, which are sections devoted to analyzing the Partai Aceh's victories.

\section{Partai Aceh Identification}

In democratic countries, political parties are strategic political instruments (Ruhenda et al., 2020). Moreover, in a democratic country, political parties formulate various political strategies to gain power. Multiple methods are used to get voters to determine their attitude towards political parties. Political issues are one of the tactics polished by political parties and political candidates in a democratic country. The main points that will be chosen in setting the political agenda, the attitudes and values they voice become a more influential political culture. The spread of an ideology is significant, whether Marxism-Leninism, National Socialism, or the idea of a leader who is considered charismatic. It is one of the main functions of political socialization or political mobilization (Heywood, 2014). In democratic practice, political socialization and mobilization are the functions of political parties to convey various party ideas (vision and mission), objectives, and political direction of parties to influence voters. Partai Aceh is one of the local political parties present in 2009 for participating in political contestants in post-conflict Aceh.

This local political party is relatively young compared to national parties such as Demokrat, PDIP, Golkar, PPP, and other national parties that have long been involved in practical politics, both at the local and national election levels. However, even though Partai Aceh is relatively young in a democratic party, this local party presence has a significant impact on the map of election competition in Aceh. Socialization is the function of political parties to inform the party's political attitudes and orientation through the political socialization process carried out by parties to the public regarding political life in society (Surbakti, 2013). The Partai Aceh carries out political socialization through internal parties, families, and communities as sympathizers of political parties. Provide political information that can change voters' attitudes to vote for parties.

Based on the results of an interview with one of the Partai Aceh officials, Mr. Riswan, stated:

"The socialization has stages through the structure of the party apparatus at each level, such as the Sagoe Leadership Council (DPS) as the administrator at the sub-district level. The briefing is carried out in the form of internal meetings and activities to the public. The political outreach carried out by the Partai Aceh also involved the role of the former Free Aceh Movement (GAM). Then, 
socialization was also carried out through several media such as banners, billboards, and other valuable media (Riswan, 2021)."

Meanwhile, a community leader named Anhar stated that the socialization carried out by the Partai Aceh was as follows:

"Partai Aceh cadres come door to door and said "neu pileh ureung tanyo!" - red (choose our people!). The goal is for the public to select a candidate from the Partai Aceh because those who understand the problems of the Helsinki MoU are political candidates with a background of former combatants (GAM). Then, they also stated that the other candidate pairs did not understand the points of the Helsinki MoU because they were not directly involved in the peace agreement between GAM and the Government of the Republic of Indonesia on 15 August 2005 in Finland. Moreover, only the Partai Aceh has and can contribute to completing the derivation of the Helsinki MoU (Anhar, 2021).

Furthermore, another community leader Mr. Salman Farisi, SE, said that the socialization was also carried out in the following ways:

"The Partai Aceh or political candidates conducted outreach in the open field by conveying problems and conditions in Aceh after the peace agreement. They stated that the Partai Aceh promised to complete and fight for the points of the Helsinki MoU so that they could be realized and achieved so that the Acehnese people would be prosperous (Salman Farisi, 2021).

Nasdem Party cadre Mr. Yunardi Natsir gave his views on the socialization carried out by the Partai Aceh, and he stated that:

"The Partai Aceh often conducts political outreach to the public by conveying the importance of forming a political superstructure, with the dominance of higher political issues, such as the issue of the Helsinki MoU and the subject of Law Number 11 of 2016 concerning Aceh Governance (UUPA). The Partai Aceh benefited from a management system from the Partai Aceh central committee to the Sagoe management in the socialization. So that the Partai Aceh can convey political education and political interests. In political socialization, the Partai Aceh was assisted by the former GAM by communicating various political interests of the Partai Aceh (Yunardi Natsir, 2021)."

Another view was also explained by the PAN cadre, Mr. Syukri, about the socialization carried out by the Partai Aceh, he stated:

"The Partai Aceh's socialization is being carried out through Partai Aceh cadres at the village level. Political socialization carried out at the village level is a PA strategy that targets voters from the community in the village. (Syukri, 2021)

Partai Aceh's process of political socialization conducts socialization through the Sagoe Leadership Council (DPS) in each sub-district, visiting houses and providing media to socialize various problems, especially political issues such as the Helsinki MoU as the political future for Aceh. Ikramatoun et al. (2019) argued that the Helsinki MoU had become the door to peace in Aceh after the prolonged conflict; peaceful ties have succeeded in disbanding the armed forces transforming into a political movement. Therefore, the Helsinki MoU is the political lifeblood of the Acehnese people, which was born from the peace agreement between GAM and the government of the Republic of Indonesia in realizing a better Aceh. The involvement of former GAM members in outreach has dramatically assisted the Partai Aceh in conducting political outreach. The socialization carried out by the Partai Aceh to the community is one of the attitudes in influencing someone to invite and elect and foster an Acehnese party attitude in society with values that are believed to exist in the community. The process of building perceptions of people's political attitudes through the political socialization process carried out by the Partai Aceh conveys political 
issues. The Helsinki MoU is a manifestation of fighting for peace and the rights of Aceh's welfare which have not been realized in the Helsinki MoU. In that way, someone who has a logical attitude when making choices will not be a problem if they have decided on the vote (Ishiyama and Beruning, 2013).

Voters will know and learn the values, norms, and political symbols of various parties in the political system from schools, government, and political parties. Political parties are educators in educating, informing, and inviting people to behave in specific ways. Political parties are tasked with providing important political information for their citizens (Ibrahim and Madjid, 2018). Voters generally find it challenging to understand all the problems and face various issues in the election. Political parties help make politics "user-friendly" for citizens. Party labels provide brief critical information about "how people should vote". After voters know which party usually represents their interests, the party also conveys a vision in political socialization. It raises a symbol of party identity and loyalty to influence voters to vote for a particular political party.

\section{Political Candidates for the Partai Aceh}

Partai Aceh recruits political candidates for general elections, regional head elections, and legislative elections behind closed doors. In determining a political candidate, the Partai Aceh will evaluate a strong figure, popularity, and political capital. The reasons for selecting candidates cannot be separated from efforts to influence voters. Voters will judge and consider which candidate will represent their vote. That way, candidates who become the identity of the political parties offered to voters must understand the characteristics of the voters.

\section{Personal Events}

Personal events refer more to private life and events that political candidates have personally experienced before becoming political candidates (Sugiono, 2013). This variable is critical to find out the personal affairs of a political candidate. Events about these political candidates will generally affect the mindset and decision-making if a candidate wins the general election. From personal circumstances, these indicators include figures from these candidates such as a kai/ulama, the daughter of a former president, a reformist figure, an activist, a professor, a businessman, and even a public figure (Sugiono, 2013). At the general election, the Partai Aceh, in determining the political candidate, was concerned about the figure who became one of the factors that changed the attitude of voters to participate in deciding their choice in the general election. Political candidate figures who are considered capable of bringing about change in society will change voters' attitudes to assess their options.

According to Yuli Zuardi Rais, one of the Partai Aceh officials stated that the determination of political candidates was carried out by bringing in candidates from internal circles who had influence and popularity among the community so that it was easy to offer political candidates to the public. The contents of the interview are as follows:

"The Partai Aceh nominates candidate pairs representing the Partai Aceh in the general election process, both for the executive election and for the legislative election, who come from internal party circles and those close to the Partai Aceh line of struggle. It is necessary so that the political leadership of the Partai Aceh remains strong with the history and continuation of the Partai Aceh struggle itself. The Partai Aceh is also open to all levels of society who wish to become candidates through a screening process at the internal level and a screening process at every level (Yuli Zuardi Rais, 2015).

The determination of political candidates who came from the Partai Aceh and who were also symbols of the struggle significantly impacted the Partai Aceh's victory. In the 2009 Legislative Election and the 2012 Aceh Pilgub, the Partai Aceh's success was greatly influenced by the promoted political candidate. In 2012, the Partai Aceh's victory was affected by the decision to carry the pair Zaini Abdullah-Muzakir Manaf (Zikir). And this is an important indicator because 
that old-young pair is a former high-ranking member of the Free Aceh Movement who has been fighting for the fate of the Acehnese through the armed movement.

This pair represents the struggle of the Acehnese people; people feel close and have an emotional relationship with a political candidate pair. This emotional connection remembers the conflict and political movement that the Partai Aceh had undertaken to convince the public. Rahmat and Savirani (2020) argued that the movement for change that grows in society, in general, can be referred to as a movement born with specific goals and interests, such as rejection of dissatisfaction with existing structures, including efforts to demand changes in institutional, policy or government systems. Thus, the candidates will lead and implement the Helsinki Memorandum of Understanding between the central government and GAM. The public believes that these two figures can improve the community's welfare because they are motivated by the sincerity of their fighters for Aceh.

The popularity of Zaini Abdullah and Muzakir Manaf (Zikir) is a distinct advantage for the Partai Aceh among the people of Aceh as a symbol of struggle and peace. The popularity of the two couples emerged since the prolonged conflict in Aceh. Nurse in Wicaksono (2009) states that one of the dimensions of political character's quality is symbolic factors that include life principles and fundamental values held by candidates, emotional aura, inspirational aura, and social aura. The popularity and personality of a former combatant promoted by the Partai Aceh received a good response from the public. The pair has a positive image and has almost no political deficiencies in society. The political candidate is considered a respected figure and meets the requirements to be elected by the community.

\section{Epistemic Issues}

Epistemic Issues are specific electoral issues and will spark voters about new things. Epistemic issues will arise amid public distrust of political institutions that are part of the current system, such as a figure capable of eradicating corruption, capable of overcoming crises, and providing security guarantees for the public (Sugiono, 2013). The Partai Aceh introduces political candidates to voters or the public, namely by presenting the candidate's events or any political issues raised by political candidates to influence voter behavior. In influencing voter behavior, Partai Aceh introduced political matters such as welfare, health, education, and security. The political problems created by the Partai Aceh influenced the attitudes of voters. According to voters' characteristics, the Partai Aceh creates interesting issues that provide insight into the Partai Aceh public. According to a community leader named Anhar, he stated that the Partai Aceh introduced political candidates in the following ways:

"The Partai Aceh in offering political candidates by telling the public that only political candidates promoted by the Partai Aceh can understand the problems in Aceh, fight for the MoU, understand the ins and outs of the struggle, where the Partai Aceh is the representative of peace between GAM and RI (Anhar, 2021).

Furthermore, another community leader named Syahrial stated that the way the Partai Aceh offered political candidates was in the following ways:

"The process of identifying candidates is carried out through meetings provided by the Partai Aceh or political candidates and introductions during the campaign by conveying the vision and mission of the candidates to the public. Candidates will offer work programs to improve welfare, be it the economy, education, health, and infrastructure needed by the community (Syahrial, 2021).

The Partai Aceh often conveys political candidates' process during political socialization conducted by the Partai Aceh and the Partai Aceh winning team. Voters will consider which political candidate to be elected. Candidates who become the identity of political parties must understand the characteristics of voters by making political bids (Firmanzah, 2012). Political candidates promoted by the Partai Aceh are trying to understand voters by offering work 
programs to improve welfare, economy, education, health, or the infrastructure needed by the community.

The issues of the MoU, security, peace, and development to create public welfare have attracted voters in Aceh. People who have lived in conflict for about 30 years don't want that anymore and hope for peace. This political issue is one of the political strategies adopted by the Partai Aceh to influence voters. According to Firmanzah (2012), the more interesting the subjects offered to the public by political parties and political candidates, the greater the chance to win in the election.

\section{The Partai Aceh Campaign Partai Aceh Political Campaign}

The campaign is an arena for political maneuver to attract as many voters as possible in an election to seize power. There are various ways to gain control, including making promises to the public or voters that sometimes don't make sense. Political parties sometimes use issues of regionalism, creating justice and prosperity, and even intimidation (Firmanzah, 2012). This political movement succeeded in conveying various offers to the public to participate in political events, coming to the voting booths to cast their votes. Political campaign movements are carried out intensively by political parties, and election campaigns are carried out at the time determined by the election organizer. Political campaigns and election campaigns submitted by the Partai Aceh or political candidates to the public are carried out to influence voter behavior. In the process of influencing voter behavior, Partai Aceh has developed a campaign strategy. Based on the results of interviews with Partai Aceh, Riswan said:

"The campaign by inviting the masses to a general meeting forum is the best moment for the Partai Aceh and its candidates to introduce themselves and convey their programs. Apart from various development programs and regional progress, the Partai Aceh has always been consistent in offering programs aligned with the aspirations for peace as set out in the Helsinki MoU. Furthermore, the campaign promises for candidates from the Partai Aceh are generally the same as for all other political candidates in each electoral district, such as development issues, budgets, and various special programs tailored to the conditions of each region (Riswan, 2021).

Furthermore, the Chairman of the KPU RI Ilham Saputra stated:

The political campaign carried out by the Partai Aceh put forward the Acehnese factor. The jargon said that only the Partai Aceh was born from the Helsinki Memorandum of Understanding (MoU) mandate. On the other hand, other local parties are not products of Helsinki. They wanted to show that the peace agreement between the Free Aceh Movement (GAM) and the Central Government of the Republic of Indonesia was an initiative of the Partai Aceh. Meanwhile, during the election campaign period, they emphasized self-government, all of which can be controlled by the people of Aceh (Ilham Saputra, 2021).

The Memorandum of Understanding (MoU) issues is different reasons for the Partai Aceh or political candidates to influence the masses as much as possible during political campaigns and election campaigns. The Partai Aceh, which has conducted election campaigns in various regions in Aceh, has influenced voters' attitudes. The issue of the Helsinki MoU has become a political trend for the Partai Aceh to control the masses because the points of the Memorandum of Understanding $(\mathrm{MoU})$ are a manifestation of the peace agreement between the Free Aceh Movement (GAM) and the government of the Republic of Indonesia. Campbell et al. (1960) said that one factor determining voters to determine their attitude is participating in the campaign.

The Partai Aceh's political campaign demonstrates a reconsolidation of the ideology of the Free Aceh Movement (GAM). This factor is a manifestation of the campaign content. They continue to identify themselves as directly involved in signing the Helsinki Memorandum of Understanding (MoU). The Helsinki Memorandum of Understanding (MoU), as stipulated in Law number 11 of 2006 concerning Aceh Governance (UUPA), can only be implemented if the Partai Aceh wins the election. 
The attitude shown by the Partai Aceh has illustrated the formation of a political image among the community. Political campaigns are closely related to forming a political vision that will influence voter behavior in evaluating the quality of election contestants (Firmanzah, 2012). Political campaigning is the most crucial part of political marketing because gaining influence in society cannot be done instantly; it takes a long process using a strategy systematically composed by political parties to gain the public's trust. An opinion was conveyed by the Nasdem Party administrator, Mr. Yunardi Natsir, regarding the campaign carried out by the Partai Aceh; he has stated:

"The Partai Aceh and political candidates often campaign on realizing the LoGA and the Helsinki MoU to solve problems in Aceh. The Partai Aceh often invites the public to remember the past conflict. Thus, the party can redeem itself at the election. In addition, the Partai Aceh conveys selfgovernment, where people can manage their government (Yunardi Nasir, 2021).

Furthermore, The PAN committee also explained another perspective regarding the candidates nominated by the Partai Aceh, usually the PA nominees' candidates. They contest the election with ideological thoughts and have prominent values in society (Syukri, 2021). The Partai Aceh is one of the local political parties that enliven political contestants during elections in Aceh. The party founded in 2007 has participated in the democratic party from 2009 to the present. Partai Aceh has won many general elections in Aceh, both at the legislative and executive election levels. This victory is not easy to come by; a mature political strategy is needed to gain power. Moreover, the Partai Aceh must compete with National Parties such as the Democrat Party, PDIP, Golkar, and PPP, the major parties in Indonesia that are politically and politically ready. However, this condition did not change the Partai Aceh to dominate local politics in Serambi Mekkah in the 2009 Legislative Election as the first election. Of course, the Partai Aceh won because they were intensive in campaigning during the election or before the election.

According to Nasdem Party administrator, Mr. Yunardi Natsir, regarding the Partai Aceh political candidate, he stated that:

"The Partai Aceh promotes candidates from former GAM in the election as part of a political strategy, intending to make it easier for the public to vote for the Partai Aceh, which has been considered to represent the struggle of the Acehnese people. The Partai Aceh conveyed the spirit of regionalism, fighting, about how the central government has treated Aceh in the past. Furthermore, the Partai Aceh expressed the role of former GAM members who fought for justice from the central government with various centralized policies (Yunardi Natsir, 2021).

Another view was also explained by the Democratic Party Cadre, Mr. Dedi Fenna, regarding the candidate promoted by the Partai Aceh, he stated:

"Candidates carried by the Partai Aceh in every election, either in the Legislative Election or regional head elections, are dominated by former GAM combatants. They think that only former GAM members understand and can realize the points of the MoU. Even though the candidates from other parties also have the political will and goals to implement the MoU and make Aceh prosperous (Dedi Fenna, 2021).

The Partai Aceh's victory on several occasions in local elections was inseparable from the political campaign strategy undertaken by the Partai Aceh. The campaign was carried out from internal Partai Aceh meetings, community meetings involving political cadres, former GAM combatants, and party sympathizers. Political strategy arrangements to strengthen votes and win were carried out. The Partai Aceh will, first of all, emphasize that its cadres must work harder. In the meetings held by the Partai Aceh, they will remind the political history of the Acehnese people about their struggles, ranging from armed struggle to the political arena. Therefore, this consolidation reminisces the past conflict. It is one of the political strategies adopted by the Partai Aceh to captivate the hearts of the Acehnese people. 
The PAN committee also explained another view, Mr. Syukri, regarding the campaign conducted by the Partai Aceh. He stated that:

"The Partai Aceh carried out the campaign by offering various pro-people programs. Still, the $P A$ elite also carried out a campaign by intervening (hidden intimidation) of the community to vote for the Partai Aceh. They said that if the Partai Aceh did not win, then Aceh would return to conflict; there was also a sentence that if the PA did not win, then Aceh's specialties in the MoU would not be realized." (Syukri, 2021)

The Partai Aceh took the political, psychological approach to influence people's emotions. The Partai Aceh also conveyed to maintain security and peace, not to let Aceh come into conflict again. Peace is the platform for building a better Aceh (Novialdi and Rassanjani, 2020). This emphasis was made to influence the people, afraid that the Partai Aceh would not win. In the meetings, the Partai Aceh invited the public to vote for the local party because the Partai Aceh was after the GAM-RI agreement. The Partai Aceh understands the agreed points of the Helsinki MoU. In Partai Aceh's political campaign, they often conduct speeches or talks about party slogans that are open to the public.

Political campaigns are organized efforts that seek to influence people's choices. In a democratic world, political campaigns are also referred to as general election campaigns. Political campaigns aim to influence prospective voters to decide on choosing candidates for executive and legislative politicians. Political campaigns are generally carried out in public meetings containing various orations, lectures, delivery of slogans, both in printed and a recorded form containing invitations, persuasions, images, or sounds and in the form of campaign symbols (Sayuti, 2014).

\section{Partai Aceh Election Campaign}

The election campaign is a political activity that aims to lead voters to the voting sites. An election campaign is the same as a political campaign seeking to influence prospective voters to elect a particular political candidate. The election campaign can only be conducted during the election schedule that the election organizer has determined. This campaign focuses more on external activities. In an election campaign, the essential thing is refreshing and strengthening people's memories about political parties.

Nasdem Party administrator, Mr. Yunardi Natsir, regarding the campaign conducted by the Partai Aceh, he stated that:

"During the campaign, the Partai Aceh delivered various non-irrational programs with political promises of 1 million per/household per month to influence the public to vote for the Partai Aceh. Not only campaigns or programs from candidates, but parties also emphasize choosing local parties as a representative form of Aceh's localization. They conveyed the campaign to the villages, even to the alleys. A more structured Partai Aceh management structure makes it easier for them to campaign to the public. The involvement of former GAM members helped facilitate the campaign (Yunardi Nasir, 2021).

Partai Aceh conducted election campaigns to attract the public by offering various programs aligned with the people's wishes in the 2012 Pilkada where the Partai Aceh nominated Zaini Abdullah-Muzakir Manaf (Zikir) regional head elections at the provincial level. The political promise in the program compiled by the couple convinced the public that the Partai Aceh political candidate could prosper Aceh. The political securities offered by the Zikir pair can be seen in Figure 3: 


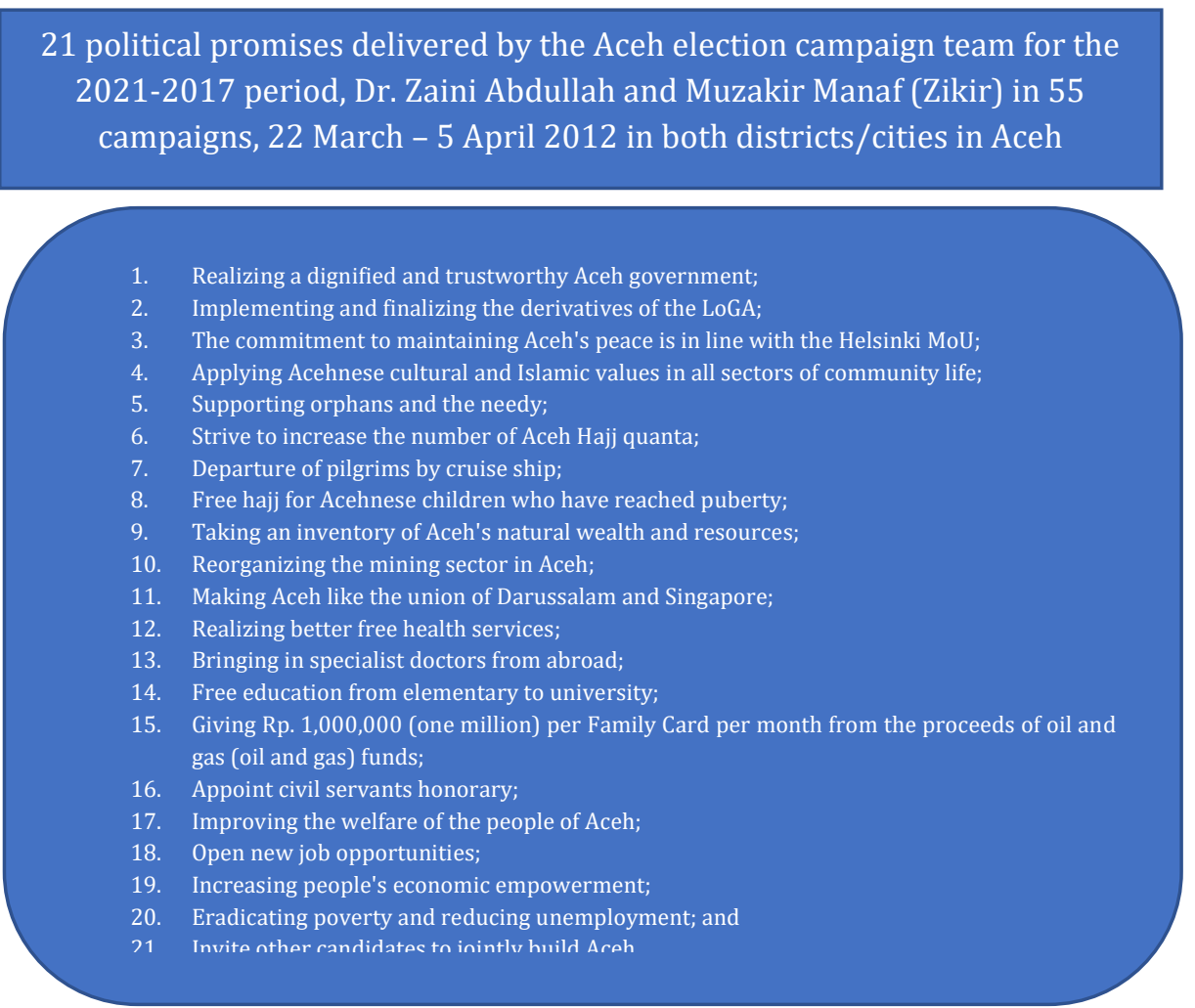

Figure 3. Political promises of Zaini Abdullah-Muzakir Manaf

In the election campaign, political parties or political candidates try to convince voters by offering political promises and hopes, candidate figures, and work programs were provided during the campaign to gain their confidence when voting was held (Firmanzah, 2012). Schroder (2004) suggested that political parties must have an identity in an election campaign, such as a partyoriented program aligned with individuals. Apart from the political campaigns carried out by the Partai Aceh in influencing voters' attitudes, of course, this issue cannot be separated from the election campaigns, political candidates, and the Partai Aceh in controlling the masses. The election campaign is a political activity leading voter to the polls. In the election campaign, the Partai Aceh tried to fight for the aspirations of the masses by offering attractive political promises to the public.

\section{CONCLUSION}

The Partai Aceh's success in political contestation in Aceh cannot be separated from the political psychology approach to identifying political parties, political candidates, and the Partai Aceh campaign. This party found some struggles before winning. The party born in 2007 must compete with the National Party, which is more experienced, has a lot of political capital and a mature political strategy. By identifying the Partai Aceh on society by involving the former Free Aceh Movement, party sympathizers impacted the political socialization process that was being carried out. The Partai Aceh has imaged itself as a party fighting for the Helsinki MoU and Law No. 11/2016 on Aceh Governance (UUPA). The success in gaining political power at the regional and local levels, both in the executive and legislative branches, cannot be separated from the political strategy adopted by the Partai Aceh. For example, the Partai Aceh's political design that carries political candidates from internal party circles (Zaini Abdullah-Muzakir Manaf), a former Free Aceh Movement, provides an excellent opportunity for the Partai Aceh win regional elections at the Aceh Province level in 2012.

The political candidates nominated by the Aceh Province The Partai Aceh is a political strategy step by presenting a figure of the former Free Aceh Movement who has been fighting for the fate of the Acehnese people from armed struggle. Their involvement during the conflict in the 
battle for Aceh's freedom from the Republic of Indonesia had a special meaning in the eyes of the Acehnese people. The political, psychological approach taken by the Partai Aceh, such as candidate figures during the campaign, gave its meaning for the community to elect the Partai Aceh in the general election. The movement that was carried out offered various pro-people programs. Still, there was also a campaign carried out by Partai Aceh elites by intervening (hidden intimidation) of the community to vote for the Partai Aceh. The party's political promises and programs provide a unique attraction for the public to vote for the Partai Aceh. One of the political promises that attract voters' attention is the program of 1 million rupiahs/head of the family each month. Other political candidates rarely carry out programs like this because their realization is difficult. Understanding voter behavior, especially the factors that influence voter behavior, is fundamental to understanding political power. When understanding voter behavior, a political party or political candidate will quickly formulate, determine, implement and evaluate strategies and approaches to winning general elections effectively and efficiently.

\section{REFERENCE}

Ahn, W. Y., Kishida, K. T., Gu, X., Lohrenz, T., Harvey, A., Alford, J. R., ... Montague, P. R. (2014). Nonpolitical Images evoke neural predictors of political ideology. Current Biology, 24(22), 2693-2699. https://doi.org/10.1016/j.cub.2014.09.050

Aspinall, E., \& Mas' udi, W. (2017). The 2017 Pilkada (local elections) in Indonesia: Clientelism, programmatic politics, and social networks. Contemporary Southeast Asia: A Journal of International and Strategic Affairs, 39(3), 417-426.

Barter, S. J. (2011). The free Aceh elections? The 2009 legislative contests in Aceh. Indonesia, (91), 113-130.

Borah, P. (2016). Political Facebook use: Campaign strategies used in 2008 and 2012 presidential elections. Journal of Information Technology \& Politics, 13(4), 326-338.

Borgida, E., Federico, C.M., \& Sullivan, J.L. (Eds.). (2009). The Political Psychology of Democratic Citizenship. Oxford, UK: Oxford University Press.

Campbell, A., Converse, P., Miller, W. E., \& Stokes, D. E. (1960). The American voter. New York: John Wiley \& Sons.

Carraro, L., Castelli, L., \& Macchiella, C. (2011). The automatic conservative: Ideology-based attentional asymmetries in the processing of valenced information. PLoS One, 6, e26456. https://doi.org/10.1371/journal.pone.0026456

Clarkson, J. J., Chambers, J. R., Hirt, E. R., Otto, A. S., Kardes, F. R., \& Leone, C. (2015). The selfcontrol consequences of political ideology. Proceedings of the National Academy of Sciences of the United States of America, 112(27), 8250-8253. https://doi.org/10.1073/pnas.1503530112

Cottam, M.L., Mastors, E., Preston, T., \& Dietz, B. (2016). Introduction to Political Psychology: 3rd Edition. Psychology Press. https://doi.org/10.4324/9780203848777

Eidelman, S., Crandall, C. S., Goodman, J. A., \& Blanchar, J. C. (2012). Low-effort thought promotes political conservatism. Personality and Social Psychology Bulletin, 38, 808-820. https://doi.org/10.1177/0146167212439213 
Firmanzah. (2012). Marketing Politik Antara Pemahaman dan Realitas. Jakarta: Yayasan Obor Indonesia.

Grimmelikhuijsen, S., Jilke, S., Olsen, A. L., \& Tummers, L. (2017). Behavioral public administration: Combining insights from public administration and psychology. Public Administration Review, 77(1), 45-56.

Haase, V. G., \& Starling-Alves, I. (2017). In search of the moral-psychological and neuroevolutionary basis of political partisanship. Dementia \& Neuropsychologia, 11(1), 1523. https://doi.org/10.1590/1980-57642016dn11-010004

Hetherington, M., \& Weiler, J. D. (2018). Prius or Pickup? How the answers to four simple questions explain America's great divide. New York: Houghton Mifflin Harcourt Publishing Company.

Heywood, A. (2014). Politik. Cet.Ke-4. Yogyakarta: Pustaka Pelajar.

Houghton, D.P. (2014). Political Psychology: Situations, Individuals, and Cases (2nd ed.). Routledge. https://doi.org/10.4324/9780203362624

Huddy, L., Sears, D. O., \& Levy, J. S. (Eds). (2013). The Oxford Handbook of Political Psychology: Second Edition. Oxford, UK: Oxford University Press.

Ibrahim, A. H. H., \& Madjid, S. (2018). The Role of Political Parties on Election Commission Performance in 2015 Mayor Election of Ternate City. International Journal of Scientific \& Technology Research, 7(2), 118-123.

Ikramatoun, S., Nusuary, F. M., \& Amin, K. (2019, January). GAM and Social Transformation, from A Rebellion into A Political Movement. In 1st Aceh Global Conference (AGC 2018) (pp. 219224). Atlantis Press.

Ishiyama, J.T., \& Breuning, M. (2013). Ilmu Politik: Dalam Paradigma Abad Ke-21. Cet. Ke-1. Jakarta: Kencana.

Jost, J. T., Stern, C., Rule, N. O., \& Sterling, J. (2017). The politics of fear: Is there an ideological asymmetry in existential motivation?. Social Cognition, 35(4), 324-353. https://doi.org/10.1521/soco.2017.35.4.324

Lakoff, G. (2016). Moral politics: How liberals and conservatives think. Chicago: University of Chicago Press.

Marcus, G.E. (2012). Political Psychology: Neuroscience, Genetics, and Politics. Oxford, UK: Oxford University Press

Mendez, M. F. (2017). A neurology of the conservative-liberal dimensions of political ideology. Journal of Clinical Neuropsychiatry and Clinical Neurosciences, 29, 86-94. https://doi.org/10.1176/appi.neuropsych.16030051

Moleong, L.J. (2007). Metode Penelitian Kualitatif. Cet. Ke-14. Bandung : PT Remaja Rosdakarya.

Nam, H. H., Jost, J. T., \& Feldman, S. (2017). The neurobiology of fairness and social justice: An introduction. Social Justice Research, 30, 289-299. 
Newman, B. I., \& Sheth, J. N. (1985). A model of primary voter behavior. Journal of Consumer Research, 12(2), 178-187.

Novialdi, R., \& Rassanjani, S. (2020). Optimizing the Ability of Aceh Province in Paradiplomacy Practice. Nation State Journal of International Studies, 3(1), 19-32.

Nuryanti, S. (2015). Intervensi penyelenggaraan pemilukada: regulasi, sumberdaya dan eksekusi. Jurnal Ilmu Sosial dan Ilmu Politik, 19(2), 125-140.

Pedersen, W. S., Muftuler, L. T., \& Larson, C. L. (2018). Conservatism and the neural circuitry of threat: Economic conservatism predicts greater amygdala-BNST connectivity during periods of threat vs. safety. Social Cognitive and Affective Neuroscience, 13(1), 43-51. https://doi.org/10.1093/scan/nsx133

Putra, R. A. (2013). Efektifitas Sosialisasi KPU Dalam Pemilukada. Jurnal Demokrasi Dan Otonomi Daerah, 10(2).

Rahmat, A., \& Savirani, A. (2020). Social Movement Ala Seniman Kota Yogyakarta Dalam Meramaikan Kontestasi Demokrasi Lokal. Journal of Governance and Social Policy, 1(2), 130-149.

Ruhenda, R., Heldi, H., Mustapa, H., \& Septiadi, M. A. (2020). Tinjauan Trias Politika Terhadap Terbentuknya Sistem Politik dan Pemerintahan di Indonesia. Journal of Governance and Social Policy, 1(2), 58-69.

Sayuti, S.D. (2014). Komunikasi Pemasaran Politik. Bandung: PT. Remaja Rosdakarya.

Schoder, P. (2004). Strategi Politik. Jakarta: Friderich Naumun Stifung.

Sinnott, J. D., \& Rabin, J. S. (Eds.). (2020). The Psychology of Political Behavior in a Time of Change. Springer International Publishing AG.

Staerklé, C. (2015). Political Psychology. International Encyclopedia of the Social \& Behavioral Sciences, 427-433. doi:10.1016/b978-0-08-097086-8.24079-8

Sugiono, A. (2013). Strategic Political Marketing: Strategi Memenangkan Setiap Pemilu (Pemilukada, Pilpres, Pemilihan Legislatif DPRD, DPR-RI, DPD) Sebagai Penentu Kemenangan. Yogyakarta: Penerbit Ombak.

Surbakti, R. (2010). Memahami Ilmu Politik. Jakarta: PT. Grasindo.

Talhelm, T., Haidt, J., Oishi, S., Zhang, X., Miao, F. F., \& Chen, S. (2015). Liberals think more analytically (more "WEIRD") than conservatives. Personality and Social Psychology Bulletin, 41(2), 250-267. https://doi.org/10.1177/0146167214563672

Tullett, A. M., Hart, W. P., Feinberg, M., Fetterman, Z. J., \& Gottlieb, S. (2016). Is ideology the enemy of inquiry? Examining the link between political orientation and lack of interest in novel data. Journal of Research in Personality, 63, 123-132. https://doi.org/10.1016/j.jrp.2016.06.018 